\title{
Erratum to: Cosmetic Outcome and Percentage of Breast Volume Excision in Oncoplastic Breast Conserving Surgery
}

\author{
Sharon W. W. Chan - Polly S. Y. Cheung • \\ S. H. Lam
}

Published online: 4 February 2010

(C) Société Internationale de Chirurgie 2010

\section{Erratum to: World J Surg}

DOI 10.1007/s00268-009-0278-x

In the original article Polly S.Y. Cheung's last name is spelled incorrectly. We apologize for this inadvertent oversight.

The online version of the original article can be found under doi:10.1007/s00268-009-0278-x.

\section{S. W. W. Chan $(\bowtie) \cdot$ S. H. Lam}

Kowloon East Cluster Breast Centre, Department of Surgery, United Christian Hospital, 130, Hip Wo Street, Kwun Tong,

Hong Kong Special Administrative Region, People's Republic of China

e-mail: sharonwwchan@yahoo.com

\section{P. S. Y. Cheung}

Hong Kong Sanatorium and Hospital, Happy Valley, Hong Kong

Special Administrative Region, People's Republic of China 